\title{
Assessment of bulls by capa-casein in the conditions of the Udmurt Republic
}

\author{
Galina Yu. Berezkina ${ }^{1 *}$,Elena M. Kislyakova ${ }^{1}$, Svetlana L. Vorobyeva ${ }^{1}$, and Konstantin E. Shkarupa ${ }^{1,2}$ \\ ${ }^{1}$ Izhevsk State Agricultural Academy, 426069 Izhevsk, Russia \\ ${ }^{2}$ Mozhgaplem Limited Liability Company, 427793 Mozhga, Russia
}

\begin{abstract}
In the article the analysis of bulls-producers used in the republic, depending on polymorphism on kcasein is carried out and the influence of genetic resources on the level of milk productivity, quality of milk and its dampness is determined. It has been revealed that $56 \%$ of bulls in the republic have AA-genotype, $40 \%$ have $\mathrm{AB}$ and only $4 \%$ have BB-genotype. The highest yield for 305 days of lactation in cows with BB- and AB-genotypes 6018 and $5985 \mathrm{~kg}$, respectively. Protein content in BB-cow milk was $3.15 \%$, which is $0.14 \%$ higher in comparison with AA-cows $(\mathrm{P} \geq 0.95)$ and AA-cows $-0.06 \%$ higher. More than a half of all milk examined in the group of cows with BB- and AB-genotype on k-casein (90 and $85 \%$, respectively) had on rennet and fermentation sample I and II class. In the Udmurt Republic $\beta$-asein contains only $26 \%$, which also affects the quality and yield of finished products, in particular, rennet cheeses.
\end{abstract}

\section{Introduction}

In dairy farming, the work aimed at finding allelic variants of the genes responsible for milk quality indicators, namely the synthesis of milk proteins, is of the greatest importance.

In recent years, scientists have focused their attention on the search for gene locuses of milk proteins such as kappa-casein, since the technological properties of milk, the quality and yield of milk products depend on their quantity and quality composition [1-3].

Numerous studies by the Institute of Tribal Affairs have established a connection between the polymorphism of the k-casein gene and animal productivity [4].

The gene of kappa-casein is one of the few known genes, which is unambiguously connected with the signs of protein and milk's technological properties. The most common are alleles A and B. B-allele of k-casein gene is associated with higher protein content in milk, higher yield of cottage cheese and cheese, as well as better coagulation properties of milk $[5,6]$.

Cows with the BB genotype have a higher protein content in milk as compared to the carriers of AA and $\mathrm{AB}$ genotypes, with $\mathrm{AB}$ animals occupying an intermediate position between $\mathrm{BB}$ and $\mathrm{AA}$ in terms of protein content.

In the Udmurt Republic, as well as in Russian Federation, the main task in dairy farming is further intensification of production aimed at increasing the genetic potential of the productive qualities of zoned breeds and creating conditions for its implementation through the use of bulls with high genetic potential.

\section{Research materials and methods}

The research was conducted in the leading breeding farms of the Udmurt Republic in the period from 2015 to 2018.

The object of the study was black-motley cows and bulls of different regions and pedigree value.

Three groups of black-motley cows were formed for experimental studies, depending on the genotype of fathers. The first group included cows obtained from bulls with k-casein AA genotype, the second group included cows obtained from bulls with k-casein AA genotype and the third group included cows obtained from bulls with k-casein AA genotype.

In the territory of the Udmurt Republic there are two plerm enterprises - LLC "Mozhgaplem" and OJSC "Udmurt". The farms of the Republic use bulls and seeds from different regions of our country - Moscow, Leningrad, Sverdlovsk, Vladimir, Novosibirsk, Perm, Udmurt Republic, as well as from Canada, France, Germany, Denmark and Holland.

The purpose of this work is to analyze the origin of bulls-producers by allelic variants of k-casein genes and to reveal the influence of k-casein polymorphism on milk quality and its damp suitability in the conditions of the Udmurt Republic.

For this purpose, the following tasks were set: to analyze the frequency of $\beta$-casein in the composition of dairy casein; to study the milk productivity of cows depending on the polymorphism of k-casein in the breeding farms of the republic; to assess the suitability of milk for cheese production.

Corresponding author: g-berezkina@ mail.ru 
The data of breeding, zootechnical and veterinary accounting, the report on the results of breeding work with cattle of black-motley breed were used in the course of scientific researches.

The analysis of milk quality and cheese production was carried out in the dairy laboratory of Izhevsk State Agricultural Academy. Cheese production was made according to TU 9225-134-0461 0209-2004.

\section{Results}

The bulls used in the farms of the republic are mainly purebred or with a high proportion of blood on Holstein breeds. Thus, 48 purebred Holstein bulls and 43 black motley bulls with blood content of 67 and $99 \%$ of Holstein breed are used at the enterprises. Productivity potential of bulls is $1111118634 \mathrm{~kg}$. Bulls-producers of breeding enterprises belong to 5 lines. The largest number of bulls belongss to the line Vis Aydial 933122 36 bulls, including 15 bulls-manufacturers of the line Vis Beck Aydial, R. Sauvring - 32 bulls, M. Ciftein - 18 bulls and 3 bulls of the line P. Governor and S.T. Rokit.

The genetic potential of bulls is diverse. Thus, the highest productivity of mothers ranges from $8050 \mathrm{~kg}$ to $16401 \mathrm{~kg}$, fat content in milk from 3.45 to $5.13 \%$, protein content in milk from 2.80 to $3.81 \%$. The productivity of fathers' mothers ranged from $8856 \mathrm{~kg}$ to $20277 \mathrm{~kg}$, fat content in milk from 3.10 to $5.33 \%$ and protein content in milk from 2.90 to $3.66 \%$.

During the analyzed period 33 bulls-manufacturers have AA-allele of the gene of kappa-casein, that makes $59 \%$ and 23 bulls or $41 \%$ of AB allele. Bulls-producers of Moscow, Leningrad and Sverdlovsk selection used in farms of the republic have mainly AA-allele of the gene of kappa-casein 83, 75 and $73 \%$, respectively. Udmurt breeding bulls and imported bulls mainly have AB-allele of the gene of kappa-casein and make up 58 and $73 \%$, respectively.

Dynamics of changes in milk yield in first calf cows, depending on the polymorphism of k-casein, is shown in Figure 1. The analysis of milk productivity of cows has shown that the highest yield for 305 days of lactation is observed in the groups of cows with BB-genotype and AB-genotype of $6018 \mathrm{~kg}$ and $5985 \mathrm{~kg}$, respectively, which is higher than the AA-animals by 314 and $281 \mathrm{~kg}$ or 5.5 and $4.3 \%$ respectively.

Protein content in BB-cow milk was $3.15 \%$, which is $0.14 \%$ higher compared to AA-cows $(\mathrm{P} \geq 0.95)$ and AAcows $-0.06 \%$ higher.

The main indicators of milk moisture content are presented in Figures 2-3.

Duration of milk coagulation with rennet enzyme in groups was 23-47 min. Such milk creates serious problems in the production of cheese and in the presence of two large cheese enterprises in the country is an important factor. However, it should be noted that the average duration of milk coagulation in cows with the genotype of $\mathrm{k}$-casein $\mathrm{BB}$ and $\mathrm{AB}$ was 23 min and 34 min, respectively, which is significantly less compared to AA-genotype cows ( $\mathrm{P} \geq 0.99)$.

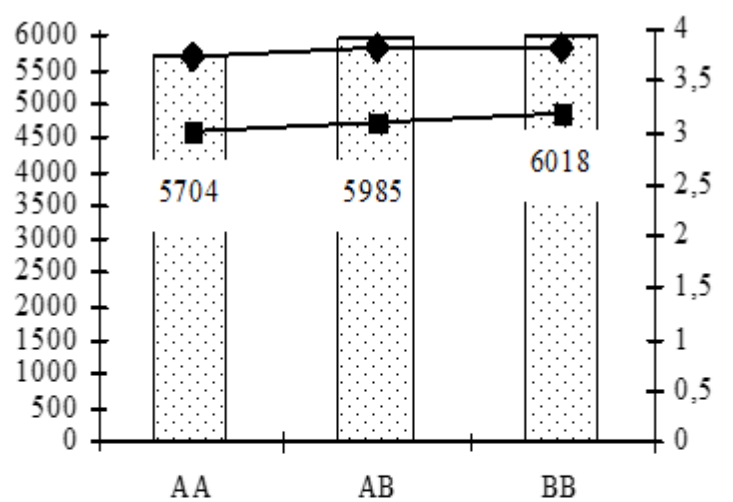

Groups of animals depending on $\mathrm{k}$-casein polymorphism

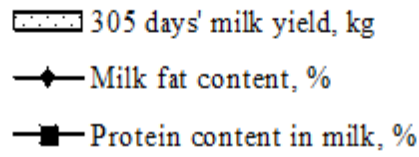

Fig. 1. Dairy cow productivity depending on k-casein polymorphism

Cheese yield is influenced by the casein content in milk. Casein content in the milk of cows of the groups under analysis ranged from 2.52 to $2.69 \%$. Thus, the casein content in the milk of BB-genotype cows was $2.69 \%$, which is higher compared to AA-genotype cows by $0.17 \%(\mathrm{P} \geq 0.99)$ and with $\mathrm{AB}$-genotype cows by $0.08 \%$.

One of the important indicators of cheese suitability is the diameter and mass of casein micelles. The larger the micelles, the more calcium phosphate on their surface and the higher their sensitivity to rennet. The largest diameter of casein micelles in the milk of cows with BB-genotype is $701.4{ }^{0} \mathrm{~A}$, which is $69.3{ }^{0} \mathrm{~A}$ or 10.9 $\%$ more than that of AA cows and $45.1{ }^{0} \mathrm{~A}$ or $6.9 \%$ compared to that of $\mathrm{AB}$ cows.

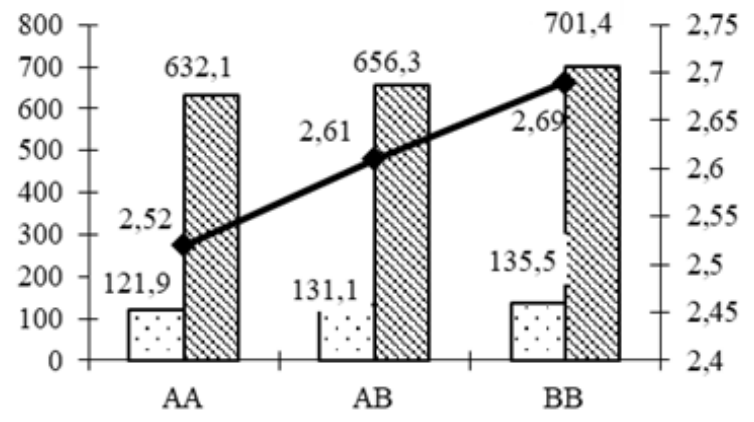

Groups of animals depending on $\mathrm{k}$-casein polymorphism

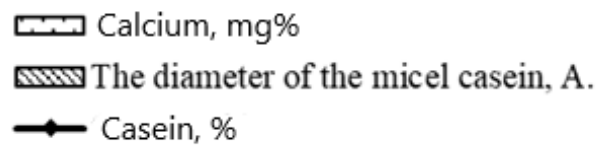

Fig. 2. Interrelation of milk quality indicators in the assessment of cheese suitability in relation to k-casein polymorphism

Milk contains such an important component for cheese-making as calcium in the range from 121.9 to 
$135.5 \mathrm{mg} \%$. According to the requirements for raw milk, the calcium content in milk should be at least $125 \mathrm{mg} \%$. In the groups analyzed, this requirement is not met only by milk of cows with AA-genotype (121.9 $\mathrm{mg} \%)$, and the difference in the groups is reliable $(\mathrm{P} \geq 0.999)$.

More than a half of the total milk examined in the group of cows with BB-genotype and AB-genotype for k-casein (90 and $85 \%$, respectively) had a rennet and fermentation sample of I or II class, i.e. when the milk was coagulated with rennet enzyme, mainly a dense one with a good separation of serum clots. Although the proportion of milk producing an undesirable clot (10 and $15 \%$, respectively) during coagulation was also high.

According to the results of the study, the rate of rennet coagulation and the quality of the protein clot have a positive effect on such indicators as the mass fraction of casein and calcium. The correlation coefficient between casein m.o. and coagulation rate was -0.19 and between casein m.o. and milk class for rennet and fermentation -0.23 ; between calcium m.o. and these indicators the correlation coefficient was -0.15 and -0.20 respectively.

The correlation coefficient between somatic cell content and milk coagulation rate was 0.10 . As a result, the most suitable milk is of cows with explosives and AB-genotype of k-casein.

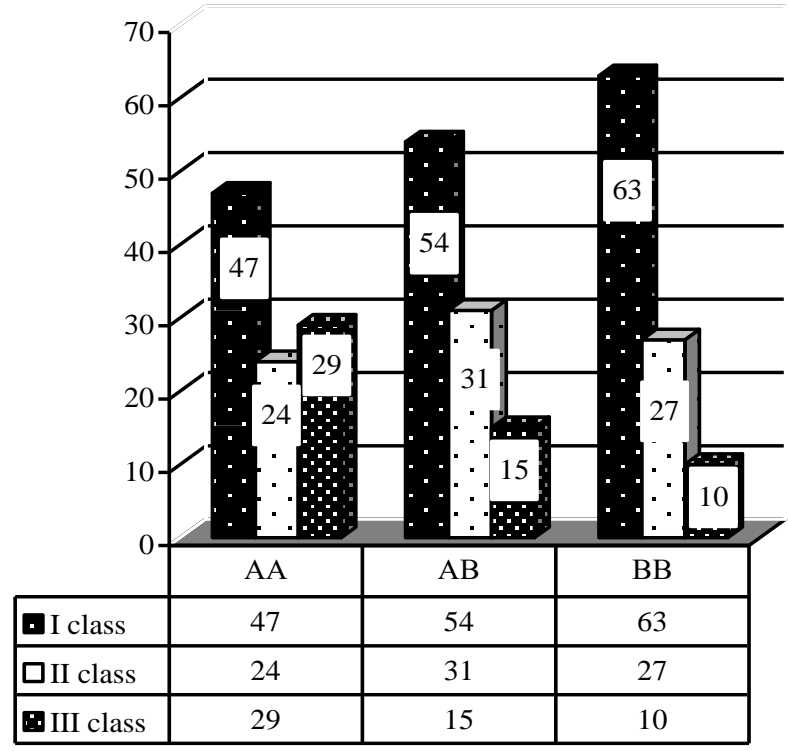

Fig. 3. Milk ratio for rennet and fermentation depending on kcasein polymorphism, \%

The results were also confirmed by the control production of Fresh Table Cheese.

When assessing the appearance, it was found that the crust of cheeses is thin, even, without damage. They have a pronounced cheese taste; consistency is elastic and uniform throughout the mass; the holes are angular in shape; the color of the test is light yellow, uniform throughout the mass. However, the cheese made from the milk obtained from cows with $\mathrm{AB}$ and $\mathrm{AA}$ genotypes has a less pronounced cheese taste and texture, as well as an uneven pattern.
According to organoleptic evaluation, cheese produced from milk of different groups can be classified as the highest grade. Thus, cheese produced from cow milk with BB genotype got 98 points out of 100 possible, $\mathrm{AB}-96$ points and in $\mathrm{AA}-91$ points, while the evaluation of taste and smell was 44,42 and 40 points, respectively. The results of the degustation evaluation of cheese are presented in table 1 .

Table 1. Appraisal by points for Fresh Table Cheese

\begin{tabular}{|c|c|c|c|c|c|c|}
\hline \multirow{3}{*}{ 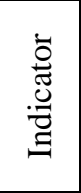 } & \multicolumn{6}{|c|}{ k-casein polymorphism } \\
\hline & \multicolumn{2}{|c|}{ AA } & \multicolumn{2}{|l|}{$\mathrm{AB}$} & \multicolumn{2}{|l|}{$\mathrm{BB}$} \\
\hline & value & $\begin{array}{l}0 \\
.0 \\
0\end{array}$ & value & $\begin{array}{l}\stackrel{0}{0} \\
.0 \\
\end{array}$ & value & 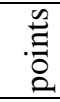 \\
\hline 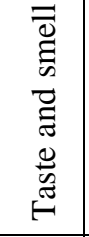 & $\begin{array}{c}\text { Good } \\
\text { taste, } \\
\text { but } \\
\text { weak } \\
\text { aroma }\end{array}$ & 40 & $\begin{array}{c}\text { Good taste, } \\
\text { but weak } \\
\text { aroma }\end{array}$ & 42 & good & 44 \\
\hline 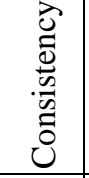 & $\begin{array}{l}\text { Good, } \\
\text { less } \\
\text { elastic }\end{array}$ & 23 & Good & 24 & Good & 24 \\
\hline$\frac{\bar{o}}{0}$ & even & 5 & even & 5 & even & 5 \\
\hline 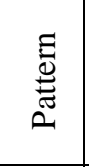 & uneven & 8 & $\begin{array}{c}\text { Characteris } \\
\text { tic for that } \\
\text { sort of } \\
\text { cheese }\end{array}$ & 10 & $\begin{array}{l}\text { Characte } \\
\text { ristic for } \\
\text { that sort } \\
\text { of cheese }\end{array}$ & 10 \\
\hline 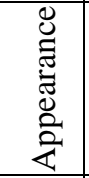 & $\begin{array}{c}\text { Charact } \\
\text { eristic } \\
\text { for } \\
\text { cheese }\end{array}$ & 10 & $\begin{array}{c}\text { Characteris } \\
\text { tic for } \\
\text { cheese }\end{array}$ & 10 & $\begin{array}{c}\text { Characte } \\
\text { ristic for } \\
\text { cheese }\end{array}$ & 10 \\
\hline 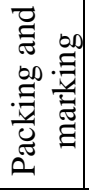 & good & 5 & good & 5 & good & 5 \\
\hline 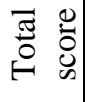 & 91 & & 96 & & 98 & \\
\hline
\end{tabular}

Physical and chemical parameters of cheese quality are presented in Table 2.

Table 2. Fresh Table Cheese Quality Indicators

\begin{tabular}{|l|c|c|c|}
\hline \multirow{2}{*}{\multicolumn{1}{|c|}{ Index }} & \multicolumn{3}{|c|}{ k-casein polymorphism } \\
\cline { 2 - 4 } & $\mathrm{AA}$ & $\mathrm{AB}$ & $\mathrm{BB}$ \\
\hline $\begin{array}{l}\text { Mass fraction of fat } \\
\text { in cheese, \% }\end{array}$ & $40.2 \pm 1.0$ & $40.0 \pm 1.2$ & $40.4 \pm 0.9$ \\
\hline Moisture, \% & $51.4 \pm 1.3$ & $52.4 \pm 0.3$ & $52.1 \pm 0.9$ \\
\hline $\begin{array}{l}\text { Milk consumption } \\
\text { per 1 kg of cheese }\end{array}$ & $9.3 \pm 0.5$ & $8.3 \pm 0.8$ & $7.8 \pm 0.5^{*}$ \\
\hline
\end{tabular}

Note: $* \mathrm{p} \leq 0.05$

In terms of physicochemical parameters, the cheese produced in different groups fully complies with the 
normative and technical documentation, but the milk consumption per $1 \mathrm{~kg}$ of cheese was lower in the group of cows with BB-genotype by $1.5 \mathrm{~kg}$ ( $\mathrm{P} \geq 0.99)$ compared to AA cows. The mass fraction of fat in the dry matter of the cheese is in the range from 40.0 to $40.4 \%$, with a norm of $40.0 \pm 1.6 \%$, and the moisture content in the cheese is $51.4-52.4 \%$, when a standard value is not more than $53.0 \%$.

\section{Conclusion}

Studies conducted in the Udmurt Republic confirm that the number of bulls with a low allele of k-casein B gene in their genotype, which affects the quality of milk in general and especially its moisture content.

In addition, it is necessary to pay attention to breeders and $\beta$-casein of milk. In studies [7-10] it was noted that $\beta$-casein accounts for up to $45 \%$ of the total casein content in milk. In the Udmurt Republic, $\beta$-casein contains only $26 \%$, which also affects the quality and yield of finished products, in particular, rennet cheeses.

Unfortunately, no large-scale studies of $\beta$-casein allelic fund have been conducted in the Russian Federation, let alone in the Republic of Udmurtia.

Cheese suitability is one of the main technological properties of milk. Particular attention is paid to this property nowadays, when dairy products with increased protein content, the main of which is cheese, are in increasing demand among the population. Milk is considered suitable for cheese production, if it has the necessary organoleptic, physicochemical, technological, biological properties and is obtained in good sanitary and hygienic conditions.

It should be noted that the republic produces quite a lot of rennet and rennet milk, i.e. milk, which is slowly coagulated or not coagulated at all by rennet enzyme. Such milk creates serious problems in the production of cheese and in the presence of two large cheese factories in the country is an important factor [11].

The main reason for the production of rennet and rennet milk and the formation of a weak clot was the admixture of abnormal milk, as evidenced by the higher content of somatic cells. The correlation coefficient between somatic cell content and milk coagulation rate was 0.10 . The reason for the formation of a weak clot in abnormal milk is the disturbed structure of the protein, the change in the ratio of casein and whey proteins, changes in the salt composition of milk. The negative influence of somatic cells themselves on the rennet coagulation rate is most likely that the enzymes released during the destruction of these cells cause casein proteolysis, the main factor of milk coagulation.

In order to obtain better quality and fuller milk, it is necessary to carry out a targeted selection to obtain a herd with a high genetic potential for protein and milk production.

From the point of view of cheese production technology it is preferable to use milk from BB-genotype cows. It has been established that milk from BB-corps possesses the minimum time of formation of a clot and its better density in comparison with milk of cows of other genotypes $[12,13]$.

\section{Acknowledgements}

The authors would like to express their gratitude to the management and zootechnical service of Mozhgaplem LLC and Udmurtskoye OJSC for their help in organizing and conducting research, as well as the university administration of Izhevsk State Agricultural Academy for the provided laboratories and equipment.

\section{References}

1. E.F. Valiullina, O.G. Zaripov, S.V. Tyulkin, T.M. Akhmetov, R.R. Vafin, Characteristics of bullsproducers with different combinations of kappacasein / betalactoglobulin genotypes by milk productivity of their mothers Veterinary practice 4(39), 59-63 (2007)

2. A.I. Lyubimov, V.A. Bychkova, O.S. Utkina, Agrarian sci. 8, 30-32 (2007)

3. A.V. Pikunova, DNA-diagnostics of kappa-casein gene in cattle Russian Agricultural Sci. Review 7, 7-1, 229-240 (2015)

4. E.M. Aliyeva, I.V. Musaeva, Polymorphism of kappa-casein gene and milk productivity of mixed primary heifers Problems of development of agroindustrial complex of the region 26, 2(26), 4144 (2016)

5. E. Kislyakova, G. Berezkina, S. Vorobyeva, S. Kokonov, I. Strelkov, Influence of using seeds of flax and raps in cow rates on the quality of milk and dairy products Bulgarian J. of Agricultural Sci. 1, 129-133 (2019)

6. O.P. Kurak, Genotyping of the population of cows of the Belarusian black-and-spruce breed by the locus of the kappa-casein gene Zootechnical sci. of Belarus, 44. 1, 111-116 (2009)

7. N.Y. Safina, A.R. Safiullina, Y.R. Yulmetyeva et al., Influence of polymorphism of prolactin and kappa-casein genes on the indices of dairy productivity of Holstein cows-bearing calves Regulatory issues in veterinary medicine 4 , 128-132 (2017)

8. R.V. Tamarova, N.G. Yarlykov, Cheese suitability of Mikhailovsky type milk Cheese-making and butter-dressing 1, 16-17 (2009)

9. R.V. Tamarova, N.G. Yarlykov, V.A. Mordvinova, Indicators determining the suitability of milk of cows of Yaroslavl breed and Mikhailovsky type Biotechnology, selection, reproduction 4(12), 38-41 (2010)

10. S.V. Titova, Modern methods of selection in dairy cattle breeding Vavilovsky J. of Genetics and Selection 4, 1040-1046 (2012)

11. S.V. Tyulkin, Encounterability of complex genotypes of kappa-casein and beta-lactoglobulin 
genes among cows of different breeds in the Republic of Tatarstan Innovative development 7(12), 49-50 (2017)

12. A.R. Shamsova, F.F. Zinnatov, A.R. Safiullina, Eurasian Scientific Association 9(31), 58-60 (2017)
13. R.R. Shaydullin, A.S. Ganiev, Assessment of polymorphism of kappa-casein gene in black-motley animals Bull. of the Ulyanovsk State Agricultural Academy 3(31), 104-109 (2015) 